Check for updates

Cite this: New J. Chem., 2017, 41,14945

Received 4th September 2017 , Accepted 28th October 2017

DOI: 10.1039/c7nj03345a

rsc.li/njc

\section{Enantioselective synthesis of substituted $\alpha$-aminophosphonates catalysed by D-glucose-based crown ethers: pursuit of the origin of stereoselectivity $\dagger$}

\author{
Son Truong Pham, ${ }^{a}$ Zsolt Rapi, ${ }^{a}$ Péter Bakó, ${ }^{a}$ Imre Petneházy, ${ }^{a}$ András Stirling (D) *b \\ and Zsuzsa Jászay ${ }^{a}$
}

Several monoaza-15-crown-5 type macrocycles annelated to phenyl- $\beta$-D-glucopyranoside were applied as chiral catalysts in enantioselective Michael addition of an $\mathrm{N}$-protected aminomethylenephosphonate onto acrylic acid derivatives and trans- $\beta$-nitrostyrene. Among these crown ethers, three are new. Michael adducts were formed with good to excellent enantio- and diastereoselectivities. Combined MM and QM calculations have revealed that suitable side arms on the crown ether beneficially affect the position of the central sodium cation, which in turn helps enhance the stereocontrol by allowing a closer contact between substrate and catalyst.

\section{Introduction}

The development of efficient methods for the enantioselective synthesis of $\alpha$-aminophosphonates has recently received much attention as these compounds are structural analogues of $\alpha$-amino acids. ${ }^{1}$ As enzyme inhibitors, they may be useful as novel herbicides, antibacterial, antihypertensive, anti-cancer, and anti-HIV agents. ${ }^{2}$ Cyclic $\alpha$-aminophosphonates have found promising applications as organocatalysts. ${ }^{3}$ Moreover, due to their chelate forming potency, aminobisphosphonic acids have become important in the treatment of osteoporosis and bone metastases. ${ }^{4}$ In addition, the practical importance of studying this class of compounds, beyond widening of basic knowledge of the reaction, is a viable research proposition as yields and enantiomeric purities can be efficiently translated into the price of pharmaceuticals.

Since biological activity is basically dependent on the configuration of the carbon atom adjacent to phosphorus, access to non-racemic $\alpha$-aminophosphonic acids by stereoselective synthesis has been the subject of intense study and has been reviewed recently. ${ }^{5}$ Reported strategies include the use of both chiral auxiliaries ${ }^{6}$ as well as catalytic $\mathrm{P}-\mathrm{C}^{7}$ and $\mathrm{C}-\mathrm{C}^{8}$ coupling.

\footnotetext{
${ }^{a}$ Department of Organic Chemistry and Technology, Budapest University of Technology and Economics, PO Box 91, Budapest 1521, Hungary

${ }^{b}$ Institute of Organic Chemistry, Research Centre for Natural Sciences, Hungarian Academy of Sciences, Budapest, Hungary.E-mail: stirling.andras@ttk.mta.hu $\dagger$ Electronic supplementary information (ESI) available. See DOI: 10.1039/ c7nj03345a
}

Chiral catalysis in conjugate additions of macrocycles annelated to various carbohydrate units has also been studied ${ }^{9}$ and reviewed in the last few decades. ${ }^{10}$ Tokke et al. were the first, who published the derivation of monoaza-15-crown-5 type crown ethers (lariat ethers) from glucose, which had substituents (side arms) on the nitrogen atom of the crown ring. ${ }^{11}$ These macrocycles derived from D-glucose are particularly attractive because of the simplicity and variability of both the chiral support and the possible side arms of the ring that hereby provide a whole family of chiral catalysts. The synthetic potential of both $\alpha$ - and $\beta$-methyl and phenyl substituted D-glucose annelated to azacrown ethers has been demonstrated in enantioselective Michael additions, Darzens condensations and epoxidations of $\alpha, \beta$-enones in the first time by our group. ${ }^{12}$ Itoh and co-workers synthesised differently bridged azacrown ethers derived from $\alpha$-D-glucose and also proved their selectivity in Michael reaction. ${ }^{13}$ We also studied the effect of the monosaccharide moieties on the chiral induction and optimized the side arm of the crown ring according to the reaction types. ${ }^{14}$

Herein, we report the application of chiral crown ethers containing a phenyl- $\beta$-D-glucopyranoside unit as phase transfer catalysts. These monoaza-15-crown-5 type macrocycles, s.c. lariat (lasso) ethers have various side arms (with a heteroatom at its terminal) at the nitrogen atom of the crown ring. Such compounds show unique guest specificity due to cooperativity of the macrocyclic side arm.

As a part of our research program on catalytic enantioselective Michael addition in general and, in particular, concerning $\alpha$ - and $\beta$-aminophosphonates, we reported alkali base promoted Michael addition of $N$-protected aminomethylenephosphonate 1 onto 
acrylic acid derivatives 2 catalysed by D-glucose-based monoaza-15-crown-5 lariat ethers ${ }^{8 d}$ 3a-d and 1,1'-bi-2-naphthylappended azacrown ethers. ${ }^{8 e}$ In these studies, we found that both types of macrocycles catalysed the addition reaction, but the stereoselectivity was only good when the Michael acceptors contained a cyano group. It also turned out that regarding selectivity, the character of the side arm of lariat ether overrides the importance of chiral support. ${ }^{8 d, e}$ Herein, we report in detail the findings described in our preliminary communication on the aforementioned addition reaction. In addition, we present new results and complete experiment with theoretical modeling to understand the origin of stereoselectivity.

\section{Results and discussion}

To have a better insight into the catalytic process operative in the above-mentioned Michael addition of $\mathrm{N}$-protected aminomethylenephosphonate $\mathbf{1}$ we wished to obtain additional information concerning the role of the side arm of our catalysts 3 and also of the Michel acceptor 2 on the stereochemical outcome of the reaction (Scheme 1).

In the present study, the synthesis and application of $\mathbf{3 e - m}$ is reported. Among them, 3k-m are new members of this series. The present catalyst set is completed by including $\mathbf{3 a - d}$ compounds, which were developed earlier. ${ }^{8}$

The new azacrowns 3k-m were synthesized using our previously elaborated method. ${ }^{11 d}$ Vicinal hydroxyl groups of a partially protected D-glucose were transformed into 2-chloroethoxyethyl derivative. Next, chlorine was exchanged for iodine using NaI. Finally, bisiodo podand, our key-intermediate 5 was submitted to $\mathrm{Na}_{2} \mathrm{CO}_{3}$ promoted ring closure with the appropriate primary amines (Fig. 1, Scheme 2).

\subsection{Synthesis of aminophosphonates 4 (Scheme 1)}

We found that all of the crown ethers tested (3a-m), in fact, catalysed the Michael addition of $N$-protected aminomethylenephosphonate 1 onto acrylic acid derivatives 2 . However, those with no side arm at all (3a) or with a hydroxypropyl side arm (3b) showed poor selectivity. Significant improvement of both catalytic activity and enantioselectivity was brought about by replacing the hydroxypropyl side chain by a methoxypropyl chain (3c) ${ }^{8 d}$ As a result of previous optimization of reaction conditions in terms of solvent, temperature, and amount of base, catalyst ${ }^{8 d}$

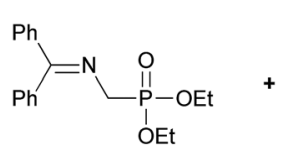

1

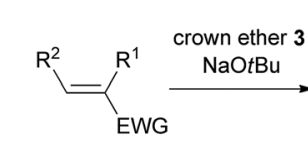

2

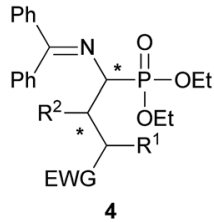

$\mathrm{R}^{1}: \mathrm{H}, \mathrm{Me}$

$\mathrm{R}^{2}: \mathrm{H}, \mathrm{Ph}$

EWG : CN, COOMe, COOEt, COOtBu, $\mathrm{NO}_{2}$

Scheme 1 Michael addition of $N$-protected aminomethylenephosphonate $\mathbf{1}$ to acrylic acids and trans-nitrostyrene $\mathbf{2}$ catalyzed by the crown ethers $\mathbf{3}$.
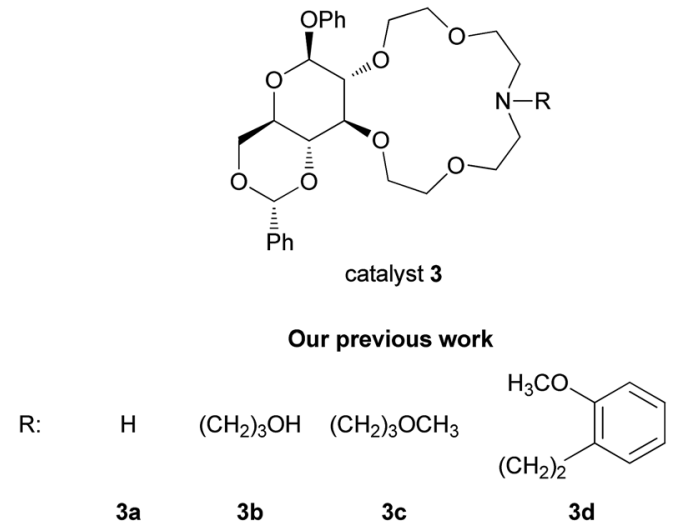

This work using known catalysts

R: $\quad\left(\mathrm{CH}_{2}\right)_{2} \mathrm{CH}_{3} \quad\left(\mathrm{CH}_{2}\right)_{2} \mathrm{OCH}_{3} \quad\left(\mathrm{CH}_{2}\right)_{4} \mathrm{OCH}_{3}$ $3 e \quad 3 f \quad 3 g$<smiles>CCCc1ccccc1</smiles>

3h

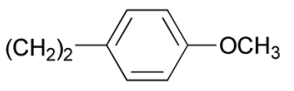

$3 \mathbf{i}$

This work using new catalysts

$\mathrm{R}:$

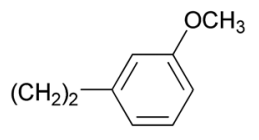

$3 \mathbf{k}$

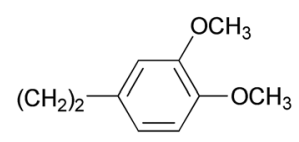

31

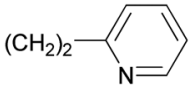

3j

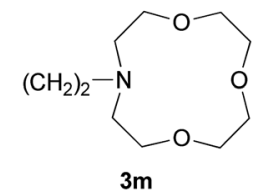

Fig. 1 D-Glucose-based azacrown ethers $3 a-m$

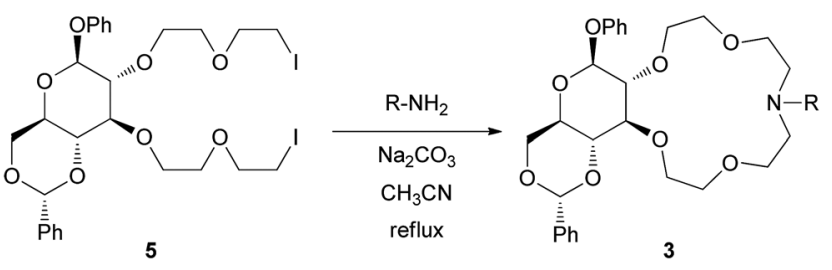

Scheme 2 Synthesis of lariat ethers 3.

additions were carried out (if not otherwise stated) at $-75{ }^{\circ} \mathrm{C}$ in toluene in the presence of solid $\mathrm{NaOtBu}$ (1.5 equiv.) as a base and with $10 \mathrm{~mol} \%$ catalyst loading.

Results are summarized in Table 1.

As demonstrated earlier, esters of both acrylic acid and transcinnamic acid reacted fast, providing the expected adduct. However, the enantioselectivity was poor (Table 1, entries 1, 2, 4-6), 
Table 1 Enantioselective Michael addition of $\mathrm{N}$-protected aminomethylenephosphonate $\mathbf{1}$ to Michael acceptors $\mathbf{2 a - i}$ using NaOtBu and catalyst $\mathbf{3 d}-\mathbf{m}$

\begin{tabular}{|c|c|c|c|c|c|c|c|c|c|c|c|}
\hline \multirow[b]{2}{*}{ Entry } & \multirow[b]{2}{*}{$\mathrm{R}^{1}$} & \multirow[b]{2}{*}{$\mathrm{R}^{2}$} & \multirow[b]{2}{*}{ EWG } & \multirow[b]{2}{*}{2} & \multirow[b]{2}{*}{ Catalyst 3} & \multirow[b]{2}{*}{ Time (min) } & \multirow[b]{2}{*}{ Conv. $^{a}(\%)$} & \multirow[b]{2}{*}{ Yield of $\mathbf{4}^{b}(\%)$} & \multirow[b]{2}{*}{$\operatorname{Dr}^{a, d}$} & \multicolumn{2}{|l|}{ ee $(\%)^{d, e}$} \\
\hline & & & & & & & & & & Major & Minor \\
\hline 1 & $\mathrm{H}$ & $\mathrm{H}$ & COOEt & $2 a$ & $3 d$ & 15 & 100 & $88(\mathbf{4 a})$ & - & $30(S)$ & \\
\hline 2 & $\mathrm{H}$ & $\mathrm{H}$ & $\mathrm{COO} t \mathrm{Bu}$ & $2 b$ & $3 d$ & 30 & 100 & $89(4 \mathbf{b})^{c}$ & - & $<5(S)$ & \\
\hline 3 & $\mathrm{H}$ & $\mathrm{H}$ & $\mathrm{CN}$ & $2 c$ & 3d & 60 & 95 & $84(4 c)^{c}$ & - & $75(S)$ & \\
\hline 4 & $\mathrm{Me}$ & $\mathrm{H}$ & COOMe & 2d & $3 d$ & 60 & 81 & $67(4 d)$ & $4: 1$ & $12(1 R, 3 R)$ & $8(1 S, 3 R)$ \\
\hline 5 & $\mathrm{Me}$ & $\mathrm{H}$ & $\mathrm{COO} t \mathrm{Bu}$ & $2 e$ & $3 d$ & 60 & 60 & $93(4 \mathbf{e})^{c}$ & $3: 1$ & 20 & 9 \\
\hline 6 & $\mathrm{H}$ & $\mathrm{Ph}$ & COOMe & $2 f$ & $3 d$ & 10 & 100 & $91(\mathbf{4 f})^{c}$ & $4: 1$ & $<5$ & 24 \\
\hline 7 & $\mathrm{Me}$ & $\mathrm{H}$ & $\mathrm{CN}$ & $2 g$ & $3 d$ & 60 & 85 & $76(\mathbf{4 g})^{c}$ & $6: 1$ & $86(1 S, 3 R)$ & $60(1 R, 3 R)$ \\
\hline 8 & $\mathrm{Me}$ & $\mathrm{H}$ & $\mathrm{CN}$ & $2 \mathrm{~g}$ & $3 d$ & 240 & 91 & $76(4 \mathrm{~g})$ & $9: 1$ & $91(1 S, 3 R)$ & $30(1 R, 3 R)$ \\
\hline 9 & $\mathrm{Me}$ & $\mathrm{H}$ & $\mathrm{CN}$ & $2 g$ & $3 e$ & 60 & 70 & $65(4 \mathrm{~g})$ & $3: 1$ & $33(1 S, 3 R)$ & $10(1 R, 3 R)$ \\
\hline 10 & $\mathrm{Me}$ & $\mathrm{H}$ & $\mathrm{CN}$ & $2 g$ & $3 f$ & 60 & 80 & $71(4 \mathrm{~g})$ & $4: 1$ & $67(1 S, 3 R)$ & $44(1 R, 3 R)$ \\
\hline 11 & $\mathrm{Me}$ & $\mathrm{H}$ & $\mathrm{CN}$ & $2 g$ & $3 f$ & 240 & 84 & $77(\mathbf{4 g})$ & $5: 1$ & $85(1 S, 3 R)$ & $45(1 R, 3 R)$ \\
\hline 12 & $\mathrm{Me}$ & $\mathrm{H}$ & $\mathrm{CN}$ & $2 g$ & $3 g$ & 60 & 84 & $72(4 \mathrm{~g})$ & $7: 1$ & $84(1 S, 3 R)$ & $59(1 R, 3 R)$ \\
\hline 13 & $\mathrm{Me}$ & $\mathrm{H}$ & $\mathrm{CN}$ & $2 \mathrm{~g}$ & $3 \mathbf{h}$ & 60 & 53 & $40(4 \mathrm{~g})$ & $3: 1$ & $41(1 S, 3 R)$ & $29(1 R, 3 R)$ \\
\hline 14 & $\mathrm{Me}$ & $\mathrm{H}$ & $\mathrm{CN}$ & $2 g$ & $3 \mathbf{i}$ & 60 & 81 & $74(4 \mathrm{~g})$ & $7: 1$ & $\begin{array}{l}88(1 S, 3 R) \\
49(1 R, 3 R)\end{array}$ & \\
\hline 15 & $\mathrm{Me}$ & $\mathrm{H}$ & $\mathrm{CN}$ & $2 g$ & $3 \mathbf{i}$ & 240 & 89 & $82(4 \mathrm{~g})$ & $9: 1$ & $92(1 S, 3 R)$ & $45(1 R, 3 R)$ \\
\hline 16 & $\mathrm{Me}$ & $\mathrm{H}$ & $\mathrm{CN}$ & $2 g$ & $3 \mathbf{k}$ & 60 & 88 & $80(\mathbf{4 g})$ & $13: 1$ & $\begin{array}{l}90(1 S, 3 R) \\
58(1 R, 3 R)\end{array}$ & \\
\hline 17 & $\mathrm{Me}$ & $\mathrm{H}$ & $\mathrm{CN}$ & $2 g$ & $3 \mathbf{k}$ & 240 & 94 & $85(4 \mathrm{~g})$ & $18: 1$ & $96(1 S, 3 R)$ & $54(1 R, 3 R)$ \\
\hline 18 & $\mathrm{Me}$ & $\mathrm{H}$ & $\mathrm{CN}$ & $2 g$ & 31 & 60 & 89 & $86(4 \mathrm{~g})$ & $12: 1$ & $91(1 S, 3 R)$ & $52(1 R, 3 R)$ \\
\hline 19 & $\mathrm{Me}$ & $\mathrm{H}$ & $\mathrm{CN}$ & $2 \mathrm{~g}$ & 31 & 240 & 94 & $89(4 \mathrm{~g})$ & $16: 1$ & $95(1 S, 3 R)$ & $57(1 R, 3 R)$ \\
\hline 20 & $\mathrm{Me}$ & $\mathrm{H}$ & $\mathrm{CN}$ & $2 g$ & $3 \mathbf{j}$ & 60 & 84 & $79(\mathbf{4 g})$ & $5: 1$ & $79(1 S, 3 R)$ & $62(1 R, 3 R)$ \\
\hline 21 & $\mathrm{Me}$ & $\mathrm{H}$ & $\mathrm{CN}$ & $2 g$ & $3 m$ & 60 & 75 & $66(4 \mathrm{~g})$ & $3: 1$ & $51(1 R, 3 R)$ & $43(1 S, 3 R)$ \\
\hline 22 & $\mathrm{H}$ & $\mathrm{Ph}$ & $\mathrm{CN}$ & $2 \mathbf{h}$ & $3 \mathbf{k}$ & 60 & 48 & $36(4 \mathbf{h})$ & $4: 1$ & 74 & 61 \\
\hline 23 & $\mathrm{H}$ & $\mathrm{Ph}$ & $\mathrm{CN}$ & $2 h$ & $3 \mathbf{k}$ & 240 & 84 & $77(4 h)$ & $6: 1$ & 78 & 63 \\
\hline 24 & $\mathrm{H}$ & $\mathrm{Ph}$ & $\mathrm{NO}_{2}$ & $2 \mathbf{i}$ & $3 \mathbf{k}$ & 60 & 79 & $70(4 \mathbf{i})$ & $3: 1$ & 71 & 57 \\
\hline 25 & $\mathrm{H}$ & $\mathrm{Ph}$ & $\mathrm{NO}_{2}$ & $2 \mathrm{i}$ & $3 \mathbf{k}$ & 240 & 89 & $81(4 \mathbf{i})$ & $5: 1$ & 74 & 59 \\
\hline
\end{tabular}

${ }^{a}$ Determined by ${ }^{31} \mathrm{P}$ NMR. ${ }^{b}$ Isolated products after column chromatography. ${ }^{c}$ See ref. $8 d .{ }^{d}$ Diastereomer ratio; determined by chiral HPLC. ${ }^{e}$ Enantiomer excess; for the absolute configuration see Fig. 2 and ref. $8 e$.

whereas while using acrylonitrile or methacrylonitrile as Michael acceptors in a 60 min reaction (entries 3 and 7), the enantioselectivity was considerably higher. ${ }^{8 d}$ After identification of $\mathbf{2 g}$ as the optimal Michael acceptor and 3d bearing 2-methoxyphenylethyl side-arm as our best catalyst so far, we screened a variety of further azacrown catalysts (3e-m) differing in their complex forming potential. We found that the $n$-butyl side arm (in 3e) did not enhance stereoselectivity (entry 9). The utilization of crown ethers with a methoxyethyl (3f) or a methoxybutyl substituent (3g) enhanced both enantio- and diastereoselectivity (entries 10 and 12). With the phenylethyl derivative (3h) (entry 13), both catalytic activity and selectivity were poor. Best results were obtained on using catalysts bearing $p$-methoxyphenylethyl, $m$-methoxyphenylethyl and 2,3-dimethoxyphenylethyl groups as side arms (3i, k and l) (entries 14, 16 and 18). A catalyst having pyridinoethyl substituent (3j) exhibited high catalytic activity but only medium stereoselectivity (entry 20). Selectivity dropped considerably in case of $\mathbf{3 m}$, a crown ether with a side chain containing three oxygen atoms (entry 21).

Our experiments have clearly shown that the presence of an oxygen atom at a certain distance (5-6 atoms) in the side arm is essential for high selectivity, presumably by providing a three-dimensional binding site for the cation. Note that all of the D-glucose appended crown ethers, except $\mathbf{3 m}$, favoured the formation of the $1 S, 3 R$-enantiomer of the adducts $4 \mathbf{g}-\mathbf{i}$. Catalyst $\mathbf{3 m}$ is a special ligand characterized by a bulky macrocyclic group at the terminal of the side arm. Therefore, it is likely to alter the mode of complexation of the catalyst resulting in an unfavourable three-dimensional intermediate complex.

To obtain more data on the scope of the stereoselectivity of the Michael reaction, trans-cinnamonitrile (2h) (entry 22) and trans-nitrostyrene (2i) (entry 24) were also examined as acceptors. These reactions were slightly slower and of lower selectivity than those with methacrylonitrile $(\mathbf{2 g})$.

Next, in order to improve yields, reaction time was extended to $240 \mathrm{~min}$. Interestingly, apart from higher conversion, in every case (entries 7/8, 10/11, 14/15, 16/17, 18/19, 22/23, 24/25) enrichment of the diastereomer $(1 S, 3 R)-4$ could also be noticed, presumably due to epimerization of $(1 R, 3 R)-4$. Longer reaction times, e.g. 360 minutes, resulted in a partial decomposition, and therefore a lower yield of the product.

Michael addition of methacrylonitrile (2g) using solid KOtBu as a base catalysed by crown ethers $3 \mathbf{c}$ and $3 \mathbf{k}$ produced the adduct (4g) with lower diastereo- and enantioselectivity (Table 2). This may be attributed to the larger size of the $\mathrm{K}^{+}$ion resulting in looser binding with the crown ether ring. Furthermore, the configuration of the major and minor diastereomers reversed compared to the one obtained with $\mathrm{NaO} t \mathrm{Bu}$ (major: $1 S, 3 R \rightarrow 1 R, 3 R)$.

\subsection{Calculations}

Force-field and $a b$ initio DFT calculations were performed to rationalize stereochemical outcome of the reactions. We considered two typical catalysts combined with two reactants leading to products $\mathbf{4 d}$ and $\mathbf{4 g}$ configured either $R$ or $S$ at the 
Table 2 Enantioselective Michael addition of $\mathbf{N}$-protected aminomethylenephosphonate $\mathbf{1}$ to methacrylonitrile $\mathbf{2}$ using KOtBu and catalyst $\mathbf{3 c}$ and $\mathbf{3 k}$

\begin{tabular}{|c|c|c|c|c|c|c|c|c|c|c|}
\hline \multirow[b]{2}{*}{ Entry } & \multirow[b]{2}{*}{$\mathrm{R}^{1}$} & \multirow[b]{2}{*}{$\mathrm{R}^{2}$} & \multirow[b]{2}{*}{ EWG } & \multirow[b]{2}{*}{ Catalyst 3} & \multirow[b]{2}{*}{ Time (min) } & \multirow[b]{2}{*}{ Conv. $^{a}(\%)$} & \multirow[b]{2}{*}{ Yield of $\mathbf{4}^{b}(\%)$} & \multirow[b]{2}{*}{$\operatorname{Dr}^{a, c}$} & \multicolumn{2}{|l|}{$\mathrm{ee}^{c, d}(\%)$} \\
\hline & & & & & & & & & Major & Minor \\
\hline 1 & $\mathrm{Me}$ & $\mathrm{H}$ & $\mathrm{CN}$ & $3 c$ & 60 & 100 & $71(4 g)$ & $2: 1$ & $61(1 R, 3 R)$ & $53(1 S, 3 R)$ \\
\hline 2 & $\mathrm{Me}$ & $\mathrm{H}$ & $\mathrm{CN}$ & $3 \mathbf{k}$ & 60 & 100 & $73(4 \mathrm{~g})$ & $1.5: 1$ & $70(1 R, 3 R)$ & $57(1 S, 3 R)$ \\
\hline
\end{tabular}

${ }^{a}$ Determined by ${ }^{31} \mathrm{P}$ NMR. ${ }^{b}$ Products isolated by column chromatography. ${ }^{c}$ Diastereomer ratio; as determined by chiral HPLC. ${ }^{d}$ Enantiomer excess; for the absolute configuration see Fig. 2 and ref. $8 e$.

Michael-donor moiety thus analysing a total of eight conceivable reaction channels.

The catalysts used are rather similar to $\mathbf{3 h}$ and $3 \mathbf{i}$ with a difference that the anomeric hydroxyl group is terminated to form $\alpha$-methoxy group in both catalysts. Since our goal was to qualitatively analyse the catalytic behaviour and the origin of stereocontrol, this simplification did not affect our final conclusions but saved computational time. We have investigated a total of 8 possible reaction channels: formation of products $\mathbf{4 d}$ and $\mathbf{4 g}$ with $R$ and $S$ configuration at the Michael-donor moiety in the presence of two different catalysts $(2 \times 2 \times 2=8)$. The structural formulae of the major products are displayed in Fig. 2.

The calculations followed the protocol elaborated earlier ${ }^{14}$ based on the plausible assumption that enantioselectivity can be predicted by the relative stabilities of intermediates following the Michael addition step in the presence of catalyst. We therefore assumed that all the interactions determining enantioselectivity were present both at the preceding transition state (TS) and in this intermediate state with similar strengths. The more endothermic the $\mathrm{C}-\mathrm{C}$ bond formation is, the more this assumption is reasonable, since the Hammond postulate indicates a larger similarity between the TS and the subsequent intermediate state. We also presume that no epimerization occurs in the subsequent steps and therefore the configuration of the enantiomeric carbon remains intact. We also note that the subsequent protonation generates an additional stereocenter in the product. In this respect, we have found that the intermediate is oriented to the crown ether in such a position that the catalyst efficiently shields one side of the prochiral centre. This geometry implies that the formation of the first chiral center determines the configuration of the second center, in accord with the generally high diastereomer ratio observed experimentally.

Due to the size and elusive nature of the systems, we selected the most likely conformations for each reaction by

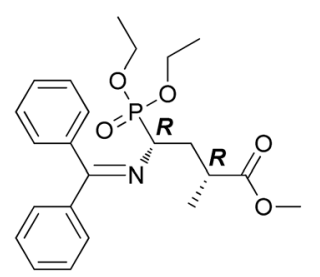

4d $(R, R)$

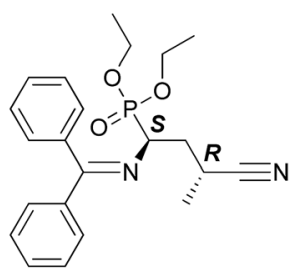

$\mathbf{4 g}(S, R)$
Fig. 2 The major stereoisomers of products $\mathbf{4 d}$ and $\mathbf{4 g}$. an extensive conformational search. We employed the OPLS force field and performed a Monte Carlo sampling of the rotatable torsions and low modes of the possible combinations of substrates and catalysts for all eight reaction paths. The structures were then minimized, and for all paths the 100 most stable structures were selected. These structures were optimized by DFT, employing the $\omega$ B97XD functional and the $6-31 \mathrm{G}^{*}$ basis set. ${ }^{15}$ Then, from each set of optimized molecules, the ten most stable structures were selected for an additional single-point energy calculation using the $6-311 \mathrm{G}^{* *}$ basis set and the SMD solvent model with toluene as the solvent. ${ }^{16}$

Our main findings and interpretations are summarized in Fig. 3. First, we compared the relative stability of the structures leading to different stereoisomers. We see that when the lariat has a $p$-methoxyphenyl termination, stereoselectivity is enhanced as opposed to termination with a phenyl group. Energy levels in the former case clearly show preference for one of the stereoisomers. For CN ligand, we see a very pronounced effect, while in case of COOMe the effect is somewhat weaker. The calculated $c a .4 \mathrm{kcal} \mathrm{mol}^{-1}$ energy difference in case of a CN ligand is sufficient to induce a very high value of enantiomeric excess (it depends exponentially on the energy differences), whereas the smaller $2.3 \mathrm{kcal} \mathrm{mol}^{-1}$ discrepancy for COOMe indicates lower enantioselectivity. In contrast, phenyl as end group induces energy differences within $1 \mathrm{kcal} \mathrm{mol}^{-1}$ (referring to the lowest energy levels), which indicates less efficient stereocontrol. In brief, the main message of the left panel is that the $p$-methoxyphenyl termination for the side-arm is beneficial for enantioselectivity.

As mentioned earlier, the arrangement of the Michaeladduct-catalyst intermediate strongly determines the configuration at $\mathrm{C} 3$ after protonation because the catalyst efficiently shields one of the prochiral faces of the intermediate. In particular, examination of these structures reveals that when the side arm is phenyl-terminated, the main products for both $\mathrm{CN}$ and COOMe are the $(S, R)+(R, S)$ pair of enantiomers. In contrast, for the 4-methoxyphenyl termination, we found that $(S, R)+(R, S)$ for EWG $=\mathrm{CN}$, while $(R, R)+(S, S)$ for EWG $=$ COOMe.

Regarding the possible structural origin of the observed stereocontrol, we point out that the large conformational freedom of the systems is manifested in various structural motifs (several close-lying conformers). However, one important motif is the position of the side arm of the crown ethers, exerting a very significant effect. Fig. 3 (right panel, top), shows a typical structure in which the lariat interacts with the cation at the opposite face relative to the substrate. In this conformation, the 

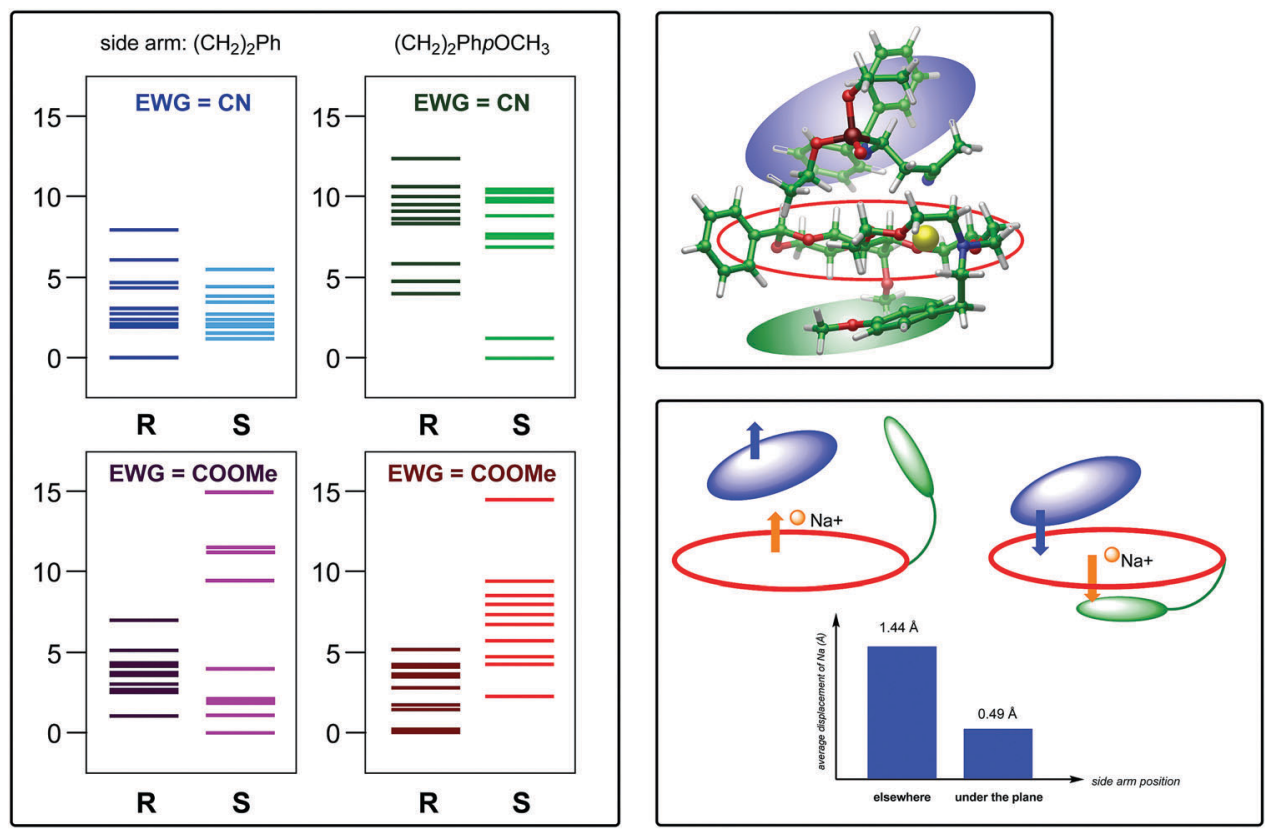

Fig. 3 Theoretical modeling of stereoselectivity in the catalytic formation of $\mathbf{4 d}$ and $\mathbf{4 g}$. Left panel: Relative stabilities (kcal mol $\left.{ }^{-1}\right)$ of stereoisomers of intermediates for the possible combinations of reactants and catalysts. Right panel top: A typical intermediate structure leading to $\mathbf{4 g}$ (in $\mathbf{S}$ configuration at the carbon atom subject to Michael addition). The lariat moiety features a $p$-methoxyphenyl group. The annotations indicate how we can derive a cartoon representation of the mechanism. Blue, red and green areas represent the substrate, the crown ether and the side arm, respectively. Right panel bottom: Simple mechanistic view of how the side arm can affect the position of the $\mathrm{Na}^{+}$cation and consequently how the reactive complex can get closer to the chiral catalyst. The graph shows average distances (in $\AA$ ) of $\mathrm{Na}^{+}$cation and the plane of crown ether for situations when (i) the side arm is in close contact with it ("under the plane") and (ii) when interaction of $\mathrm{Na}^{+}$is inhibited ("elsewhere").

sodium cation can simultaneously interact with the substrate anion and the aromatic ring of the lariat. In such situations, the sodium ion remains very close to the crown ring. In fact, considering all the structures in which this situation occurs, an average $0.5 \AA$ displacement from the plane of the crown ether could be obtained (the plane of the crown ether ring is defined as the least-square plane of the oxygen atoms) as shown in the diagram in the bottom right panel of Fig. 3. In contrast, when the orientation of the side arms does not allow such simultaneous interaction, the average displacement of $\mathrm{Na}^{+}$is $1.44 \AA$ (towards the substrate). This large effect has an important implication that the catalyst can exert a stronger chiral control on the substrate when it is pulled closer to the crown ether by the sodium cation. Although we could not see a uniform lariat orientation in most of the substrate + catalysts sets studied, a significantly higher population of favourable situations was found when the side arm was terminated by 4-methoxyphenyl group. This can be rationalized by the more electron-rich $p$-methoxyphenylsodium ion interaction due to the presence of the $\mathrm{OCH}_{3}$ group, which then contributed to an enhanced stereoselectivity predicted for these catalysts. This mechanism is depicted in Fig. 3 (right panel, bottom), where the average displacements of sodium are also shown. Further support for the proposed mechanism is provided by the experiment as follows: when sodium was replaced by potassium, stereoselectivity dropped since the larger size of the $\mathrm{K}^{+}$cation prevented it from obtaining close proximity with the crown ether and substrate, and thus the latter could not sufficiently approach the catalyst.

\section{Conclusions}

Synthesis of a series of new D-glucose appended lariat ethers $\mathbf{3} \mathbf{j}-\mathbf{m}$ and their application along with earlier synthesized crown ethers $\mathbf{3 e - j}$ in a stereoselective phase transfer catalytic Michael-addition of $N$-protected aminomethylenephosphonates $\mathbf{1}$ onto acrylic acid derivatives and trans- $\beta$-nitrostyrene 2 have been reported. The Michael-addition proceeds with high enantioselectivity (ee: $91-96 \%$ ) to acrylonitrile and methacrylonitrile, with medium stereoselectivity (ee: $74-78 \%$ ) to trans-cinnamonitrile and trans-nitrostyrene and with very low enantioselectivity (ee: $<5-30 \%$ ) to esters of acrylic, methacrylic and cinnamic acid. Adducts $\mathbf{4 a - i}$ are considered as versatile building blocks for the preparation of functionalized enantiopure $\alpha$-aminophosphonates and phosphonopeptides. Theoretical modeling of stereoselectivity in the catalytic formation of the adducts rationalized the absolute configuration of the predominant adducts $\mathbf{4 d}(1 R, 3 R$ for the major diastereomer) and $\mathbf{4 g}(1 S, 3 R$ for the major diastereomer). The pronounced influence of the side arm of the crown ethers $3 \mathbf{h}$ and $3 \mathbf{i}$ was also rationalized by our calculations. A mechanism is proposed where the strength of interaction between lariat and sodium cation is correlated with stereoselectivity. This mechanism also provides an explanation for the decline in stereoselectivity when $\mathrm{Na}^{+}$is replaced by $\mathrm{K}^{+}$. 


\section{Experimental}

General

NMR spectra were recorded on Bruker Avance-DRX-500 and 300 instruments using tetramethylsilane $\left({ }^{1} \mathrm{H},{ }^{13} \mathrm{C}\right)$ as internal standard and $85 \% \mathrm{H}_{3} \mathrm{PO}_{4}\left({ }^{31} \mathrm{P}\right)$ as external standard, all in $\mathrm{CDCl}_{3}$ solution. High-resolution MS measurements were carried out on a Waters LCT Premier XE spectrometer coupled with Acquity UPLC system [ESI, $2.5 \mathrm{kV}$ spray voltage, $250{ }^{\circ} \mathrm{C}$ capillary temperature, solvent: $\mathrm{CH}_{3} \mathrm{CN}\left(+0.035 \mathrm{v} / \mathrm{v} \%\right.$ TFA) : $\mathrm{H}_{2} \mathrm{O}(+0.05 \mathrm{v} / \mathrm{v} \%$ TFA) grad: $5-95 \% \mathrm{CH}_{3} \mathrm{CN}$ ]. Mass spectra for $\mathbf{3 k}$ and $3 \mathbf{m}$ were measured on a Varian MAT312 instrument. Thin layer chromatography was performed on silica gel plates (60 GF-254, Merck), while column chromatography was carried out using Silica gel 60 (0.063-0.2 mm, Merck). HPLC measurements were carried out on Jasco PU 1580 equipment supplied with a Jasco UV1575 detector. Optical rotations were measured with Perkin Elmer 241 polarimeter at room temperature.

\section{General procedure for the synthesis of catalysts $3 \mathbf{k}-\mathbf{m}$}

Compound $5(1.48 \mathrm{~g}, 2.05 \mathrm{mmol})$ and the amine component $(2.22 \mathrm{mmol})$ in $30 \mathrm{ml}$ abs. MeCN were stirred and refluxed with an excess of dry $\mathrm{Na}_{2} \mathrm{CO}_{3}$ (1.40 g) for 16-24 h under argon. After completion of the reaction, the suspension was filtered and the filtrate was concentrated. The residue was taken up in chloroform $(20 \mathrm{~mL})$, washed twice with water $(20 \mathrm{ml})$, dried over $\mathrm{Na}_{2} \mathrm{SO}_{4}$ and concentrated. The crude product was viscous oil, purified by column chromatography using $\mathrm{CH}_{2} \mathrm{Cl}_{2}-\mathrm{MeOH}=$ $95: 5$ as an eluent.

Phenyl-4,6-O-benzylidene-2,3-dideoxy- $\beta$-D-glucopyranosido[2,3h]- $N$-(3-methoxyphenethyl)-1,4,7,10-tetraoxa-13-azacyclopentadecane $(3 \mathrm{k})$. White powder, $[\alpha]_{\mathrm{D}}^{22}=-40$ (c 1, $\left.\mathrm{CHCl}_{3}\right)$. ${ }^{1} \mathrm{H}-\mathrm{NMR}\left(500 \mathrm{MHz}\right.$ ), $\delta$ (ppm): 2.65-2.88 (m, 4H, $\mathrm{CH}_{2} \mathrm{NCH}_{2}$, $\left.2 \mathrm{H}, \mathrm{CH}_{2} \mathrm{Ar}\right), 2.90-3.05\left(\mathrm{~m}, 2 \mathrm{H}, \mathrm{CH}_{2} \mathrm{~N}\right), 3.42-3.85(\mathrm{~m}, 13 \mathrm{H}$, $\left.5 \times \mathrm{CH}_{2} \mathrm{O}, \mathrm{H}-4, \mathrm{H}-3, \mathrm{H}-2\right), 3.79\left(\mathrm{~s},{ }_{3} \mathrm{H}, \mathrm{CH}_{3} \mathrm{O}\right), 3.96-4.04$ (m, 3H, $\left.\mathrm{OCH}_{2}, \mathrm{H}-6 \mathrm{~b}\right), 4.08$ (td, $\left.J=10.5 \mathrm{~Hz}, 2.6 \mathrm{~Hz}, 1 \mathrm{H}, \mathrm{H}-5\right)$, 4.36 (dd, $J=10.5 \mathrm{~Hz}, 5.0 \mathrm{~Hz}, 1 \mathrm{H}, \mathrm{H}-6 \mathrm{a}) 5.07$ (d, $J=7.7 \mathrm{~Hz}, 1 \mathrm{H}$, $\mathrm{H}-1), 5.55$ (s, 1H, PhCH), 6.72-6.75 (m, 2H, ArH), 6.78 (d, J = $7.54 \mathrm{~Hz}, 1 \mathrm{H}, \mathrm{ArH}) 7.01-7.04$ (m, 2H, ArH), 7.07 (d, $J=7.61 \mathrm{~Hz}$, 1H, ArH), 7.19 (dd, $J=8.41 \mathrm{~Hz}, 7.52 \mathrm{~Hz}, 1 \mathrm{H}, \mathrm{ArH}), 7.27-7.33$ (m, 2H, ArH), 7.34-7.40 (m, 3H, ArH), 7.46-7.51 (m, 2H, ArH). ${ }^{13} \mathrm{C}-\mathrm{NMR}(60 \mathrm{MHz}), \delta(\mathrm{ppm}): 34.24\left(\mathrm{CH}_{2} \mathrm{Ph}\right), 54.22\left(\mathrm{CH}_{2} \mathrm{~N}\right)$, $54.32\left(\mathrm{CH}_{2} \mathrm{~N}\right), 55.37\left(\mathrm{CH}_{2} \mathrm{~N}\right), 58.76\left(\mathrm{CH}_{3} \mathrm{O}\right), 66.32(\mathrm{CHO}), 68.94$ $\left(\mathrm{CH}_{2} \mathrm{O}\right), 70.60\left(\mathrm{CH}_{2} \mathrm{O}\right), 70.68\left(\mathrm{CH}_{2} \mathrm{O}\right), 72.59\left(\mathrm{CH}_{2} \mathrm{O}\right), 72.70$ $\left(\mathrm{CH}_{2} \mathrm{O}\right), 81.19$ (CHO), 81.72 (CHO), 81.94 (CHO), 101.43 (OCHO), 102.36 (OCHO), $111.48(\mathrm{Ph}), 114.78(\mathrm{Ph}), 117.16(\mathrm{Ph})$, $121.36(\mathrm{Ph}), 123.25(\mathrm{Ph}), 126.24(\mathrm{Ph}), 128.49(\mathrm{Ph}), 129.23(\mathrm{Ph})$, $129.53(\mathrm{Ph}), 129.82(\mathrm{Ph}), 137.45\left(\mathrm{Ph}_{\mathrm{q}}\right), 157.28\left(\mathrm{Ph}_{\mathrm{q}}\right), 159.83$ $\left(\mathrm{Ph}_{\mathrm{q}}\right)$. ESI-MS, $m / z: 636.4[\mathrm{M}+\mathrm{H}]^{+} ; 658.4[\mathrm{M}+\mathrm{Na}]^{+}$.

Phenyl-4,6-O-benzylidene-2,3-dideoxy- $\beta$-D-glucopyranosido$[2,3 h]-N$-(3,4-dimethoxyphenethyl)-1,4,7,10-tetraoxa-13-azacyclopentadecane (3l). White powder, $[\alpha]_{\mathrm{D}}^{22}=-46$ (c 1, $\left.\mathrm{CHCl}_{3}\right)$. ${ }^{1} \mathrm{H}-\mathrm{NMR} \quad(500 \mathrm{MHz}): \delta$ (ppm): 2.62-2.66 (m, $2 \mathrm{H}, \mathrm{CH}_{2} \mathrm{~N}$ $\left.2 \mathrm{H}, \mathrm{CH}_{2} \mathrm{Ar}\right), 2.73-2.89\left(\mathrm{~m}, 4 \mathrm{H}, \mathrm{CH}_{2} \mathrm{NCH}_{2}\right), 3.42-3.71(\mathrm{~m}$, $\left.7 \times 2 \mathrm{H}, \mathrm{O}-\underline{\mathrm{CH}}_{2}\right), 3.78(\mathrm{~s}, 3 \mathrm{H}), 3.8(\mathrm{~s}, 3 \mathrm{H}), 3.92-3.93(\mathrm{~m}, 1 \mathrm{H}$, $\mathrm{CH}_{2}-\mathrm{O}-\underline{\mathrm{C}} \underline{\mathrm{H}}-\underline{\mathrm{C}} \underline{\mathrm{H}}-\mathrm{O}-\mathrm{CH}_{2}$ ), 3.91-3.94 (m, 3H, $\left.\mathrm{OCH}_{2}, \mathrm{H}-6 \mathrm{~b}\right), 4.24$ $\left(\mathrm{dd}, J_{\mathrm{HH}}=5 \mathrm{~Hz}, 10.5 \mathrm{~Hz}, 1 \mathrm{H}, \mathrm{H}-6 \mathrm{a}\right), 5.0\left(\mathrm{~d}, 1 \mathrm{H}, J_{\mathrm{HH}}=7.65 \mathrm{~Hz}\right.$,

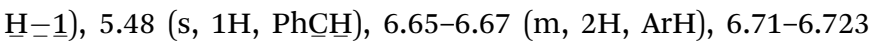
(m, 1H, ArH), 6.95-7.08 (m, 3H, ArH), 7.22-7.52 (m, 2H, ArH), 7.29-7.31 (m, 1H, ArH), 7.36-7.42 (m, 2H, ArH). ${ }^{13} \mathrm{C}-\mathrm{NMR}$ $(60 \mathrm{MHz}): \delta$ (ppm): $33.82\left(\mathrm{CH}_{2} \mathrm{Ph}\right), 54.15\left(\mathrm{CH}_{2} \mathrm{~N}\right), 54.26$ $\left(\mathrm{CH}_{2} \mathrm{~N}\right), 55.92\left(\mathrm{CH}_{3} \mathrm{O}\right), 56.11\left(\mathrm{CH}_{3} \mathrm{O}\right), 59.06\left(-\mathrm{O}-\mathrm{C}+\mathrm{H}_{-} \mathrm{CH}_{2}-\mathrm{O}-\right)$, 66.16 (CHO), $68.78\left(\mathrm{CH}_{2} \mathrm{O}\right), 70.59\left(\underline{\mathrm{C}}_{2} \underline{\mathrm{O}}\right), 70.67\left(\underline{\mathrm{C}}_{2} \underline{\mathrm{O}}\right), 72.55$ $\left(\mathrm{CH}_{2} \mathrm{O}\right), 72.67\left(\mathrm{CH}_{2} \mathrm{O}\right), 81.06(\mathrm{CHO}), 81.57$ (CHO), $81.80(\mathrm{CHO})$,

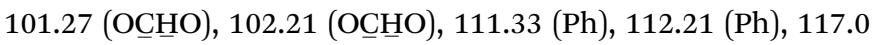
(Ph), 120.62 (Ph), 123.09 (Ph), 126.07 (Ph), $128.32(\mathrm{Ph}), 129.06$ (Ph), $129.65(\mathrm{Ph}), 137.3\left(\mathrm{Ph}_{\mathrm{q}}\right), 148.87\left(\mathrm{Ph}_{\mathrm{q}}\right), 157.11\left(\mathrm{Ph}_{\mathrm{q}}\right)$, FABMS $m / z 666.3267$ (measured $\mathrm{NH}^{+}$), 666.3278 (calc. $\mathrm{MH}^{+}$).

Phenyl-4,6- $O$-benzylidene-2,3-dideoxy- $\alpha$-D-glucopyranosido$[2,3 h]-N$-(2-(1,4,7-trioxa-10-azacyclododecan-10-yl)ethyl)-1,4,7,10tetraoxa-13-azacyclopentadecane (3m). ${ }^{1} \mathrm{H}-\mathrm{NMR} \quad(500 \mathrm{MHz})$ : $\delta$ (ppm): 2.54-2.81 (m, 8H, $\left.\mathrm{CH}_{2} \mathrm{NCH}_{2}\right), 2.85-2.95(\mathrm{~m}, 4 \mathrm{H}$, $\mathrm{CH}_{2} \mathrm{~N}$ ), 3.42-3.85 (m, 22H, $\left.11 \times \mathrm{CH}_{2} \mathrm{O}, \mathrm{H}-4, \mathrm{H}-3, \mathrm{H}-2\right), 3.96-$ 4.04 (m, 3H, $\left.\mathrm{OCH}_{2}, \mathrm{H}-6 \mathrm{~b}\right), 4.15$ (td, $\left.J=10.5 \mathrm{~Hz}, 2.6 \mathrm{~Hz}, 1 \mathrm{H}, \mathrm{H}-5\right)$, 4.22 (dd, $J=10.5 \mathrm{~Hz}, 5.0 \mathrm{~Hz}, 1 \mathrm{H}, \mathrm{H}-6 \mathrm{a}), 4.96$ (d, $J=7.7 \mathrm{~Hz}, 1 \mathrm{H}$, $\mathrm{H}-1$ ), 5.48 (s, 1H, PhCH), 6.85-7.02 (m, 3H, ArH), 7.20-7.42 $(\mathrm{m}, 7 \mathrm{H}, \mathrm{ArH}) .{ }^{13} \mathrm{C}-\mathrm{NMR}(60 \mathrm{MHz}): \delta(\mathrm{ppm}): 53.81\left(\mathrm{CH}_{2} \mathrm{~N}\right)$, $54.30\left(\mathrm{CH}_{2} \mathrm{~N}\right), 55.37\left(\mathrm{CH}_{2} \mathrm{~N}\right), 55.75\left(\mathrm{CH}_{2} \mathrm{~N}\right), 67.24(\mathrm{CHO}), 69.2$ $\left(\mathrm{CH}_{2} \mathrm{O}\right), 69.9\left(\mathrm{CH}_{2} \mathrm{O}\right), 70.60\left(\mathrm{CH}_{2} \mathrm{O}\right), 72.35\left(\mathrm{CH}_{2} \mathrm{O}\right), 72.61\left(\mathrm{CH}_{2} \mathrm{O}\right)$, 80.55 (CHO), 81.32 (CHO), 81.77 (CHO), 101.81 (OCHO), 102.28 (OCHO), 111.27 (Ph), 112.31 (Ph), 117.0 (Ph), $120.62(\mathrm{Ph}), 123.09$ (Ph), $126.07(\mathrm{Ph}), 127.61(\mathrm{Ph}), 128.32(\mathrm{Ph}), 137.23\left(\mathrm{Ar}_{\mathrm{q}}\right), 158.54$ $\left(\mathrm{Ar}_{\mathrm{q}}\right)$. ESI-MS, $m / z: 359.5[\mathrm{M}+2 \mathrm{H}]^{2+} ; 717.4[\mathrm{M}+\mathrm{H}]^{+}$.

\section{General procedure for the synthesis of 4}

The stirred mixture of $\mathbf{1}(0.5 \mathrm{~g}, 1.5 \mathrm{mmol})$, catalyst $3(0.15 \mathrm{mmol})$ and $\mathrm{NaO} t \mathrm{Bu}(0.192 \mathrm{~g}, 2 \mathrm{mmol})$ in abs. toluene $(7 \mathrm{~mL})$ was cooled to $-78{ }^{\circ} \mathrm{C}$ under an argon atmosphere. After 10 minutes, the toluene solution $(3 \mathrm{~mL})$ of the acrylic acid derivative 2 $(1.8 \mathrm{mmol})$ was added. After stirring for the given time at $-78{ }^{\circ} \mathrm{C}$ the reaction was quenched with saturated aqueous $\mathrm{NH}_{4} \mathrm{Cl}$ and extracted with toluene. The combined organic extracts were dried over $\mathrm{MgSO}_{4}$, and the toluene was evaporated under reduced pressure. Products 4 were isolated by column chromatography on silica using EtOAc-hexane $=7: 3$ (for $\mathbf{4 a}, \mathbf{f}, \mathbf{g}, \mathbf{h}$ and $\mathbf{i}$ ) and $\mathrm{CH}_{2} \mathrm{Cl}_{2}-\mathrm{MeOH}=9: 1$ (for 4 d) as eluent. Catalysts 3 were also recovered during the column chromatography.

4-(Benzhydrylidene-amino)-4(diethoxy-phosphoryl)-butyric acid ethyl ester (4a). M.p. $30-33{ }^{\circ} \mathrm{C}$. $[\alpha]_{\mathrm{D}}^{20}=5.6\left(c\right.$ 1.0, $\left.\mathrm{CHCl}_{3}\right)$. ${ }^{1} \mathrm{H}$ NMR (300 MHz): $\delta(\mathrm{ppm}): 1.18\left(3 \mathrm{H}, \mathrm{t}, J_{\mathrm{HH}}=7.2 \mathrm{~Hz}\right), 1.31$ $\left(3 \mathrm{H}, \mathrm{t}, J_{\mathrm{HH}}=7.1 \mathrm{~Hz}\right), 1.36\left(3 \mathrm{H}, \mathrm{t}, J_{\mathrm{HH}}=7.1 \mathrm{~Hz}\right), 2.16-2.37$ (4H, m), 3.90-3.95 (1H, m), $4.05\left(2 \mathrm{H}, \mathrm{q}, J_{\mathrm{HH}}=7.2 \mathrm{~Hz}\right), 4.11-4.34$ (4H, m), 7.30-7.53 (10H, m). ${ }^{13} \mathrm{C} \mathrm{NMR} \mathrm{(60} \mathrm{MHz):} \delta(\mathrm{ppm}): 14.1$, $16.4,16.5,26.3\left(\mathrm{~d}, J_{\mathrm{PC}}=4.2 \mathrm{~Hz}\right), 31.2\left(\mathrm{~d}, J_{\mathrm{PC}}=15.1 \mathrm{~Hz}\right), 60.3,60.6$ $\left(\mathrm{d}, J_{\mathrm{PC}}=158.6 \mathrm{~Hz}\right), 62.4\left(\mathrm{~d}, J_{\mathrm{PC}}=7.1 \mathrm{~Hz}\right), 62.7\left(\mathrm{~d}, J_{\mathrm{PC}}=7.1 \mathrm{~Hz}\right)$, 127.95 (Ph), $128.2(\mathrm{Ph}), 128.4(\mathrm{Ph}), 128.6(\mathrm{Ph}), 128.8(\mathrm{Ph}), 130.3$ (Ph), 133.8 (Ph), 135.7 (Ph), 139.2 (Ph), 170.0 (CN), 172.8 (CO). ${ }^{31}$ P NMR: (121.5 MHz): $\delta$ (ppm): 23.7. FAB-MS $m / z 432.4[\mathrm{M}+1]^{+}$ (calcd 431.46).

4-(Benzhydrylidene-amino)-4(diethoxy-phosphoryl)-2-methylbutyric acid methyl ester (4d). Colorless oil. HPLC conditions: Chiralpack AD-H (hexane-IPA 95:5, flow rate: $0.8 \mathrm{ml} \mathrm{min}^{-1}$, 
$256 \mathrm{~nm}, 20{ }^{\circ} \mathrm{C}$ ) major diastereomer: $t_{\text {major }}=6.8 \mathrm{~min}$ and $t_{\text {minor }}=$ $12.8 \mathrm{~min}$; minor diastereomer: $t_{\text {major }}=9.1 \mathrm{~min}$ and $t_{\text {minor }}=$ $65.1 \mathrm{~min}$. Major diastereomer: ${ }^{1} \mathrm{H}$ NMR (500 MHz): $\delta(\mathrm{ppm})$ : $1.14(\mathrm{~d}, J=7.1 \mathrm{~Hz}, 3 \mathrm{H}), 1.35(\mathrm{t}, J=7.1 \mathrm{~Hz}, 6 \mathrm{H}), 2.0-2.24(\mathrm{~m}, 1 \mathrm{H})$, 2.24-2.38 (m, 1H), 2.40-2.58 (m, 1H), $3.42(\mathrm{~s}, 3 \mathrm{H}), 3.90-4.02$ (m, 1H), 4.03-4.27 (m, 4H), 7.20-7.62 (m, 10H). ${ }^{13} \mathrm{C} \mathrm{NMR} \mathrm{(60} \mathrm{MHz):}$ $\delta$ (ppm): 16.35, $\left(\mathrm{OCH}_{2} \mathrm{CH}_{3}\right), 16.56\left(\mathrm{OCH}_{2} \mathrm{CH}_{3}\right), 17.95\left(\mathrm{CHCH}_{3}\right)$, $31.24\left(\mathrm{~d}, J_{\mathrm{PC}}=4.2 \mathrm{~Hz}, \mathrm{CH}_{2}\right), 37.40\left(\mathrm{~d}, J_{\mathrm{PC}}=15.0 \mathrm{~Hz}, \mathrm{CHCO}\right), 51.2$ $\left(\mathrm{OCH}_{3}\right), 59.52\left(\mathrm{~d}, J_{\mathrm{PC}}=153 \mathrm{~Hz}, \mathrm{CHP}\right), 62.26\left(\mathrm{~d}, J_{\mathrm{PC}}=6.60 \mathrm{~Hz}\right.$, $\mathrm{POCH}_{2} \mathrm{CH}_{3}$ ), 62.68 (d, $\left.J_{\mathrm{PC}}=6.70 \mathrm{~Hz}, \mathrm{POCH}_{2} \mathrm{CH}_{3}\right), 127.95(\mathrm{Ph})$, $128.41(\mathrm{Ph}), 128.45(\mathrm{Ph}), 128.57(\mathrm{Ph}), 128.71(\mathrm{Ph}), 128.84(\mathrm{Ph})$, $128.86(\mathrm{Ph}), 128.93(\mathrm{Ph}), 130.18(\mathrm{Ph}), 130.28(\mathrm{Ph}), 135.70$ (Ph), 135.74 (Ph), 137.53 (Ph), $139.58(\mathrm{Ph}), 168.85$ (CN), 174.56 (CO). ${ }^{31} \mathrm{P}$ NMR (121 MHz): $\delta$ (ppm): 24.2. Minor diastereomer: ${ }^{1} \mathrm{H}$ NMR (500 MHz): $\delta$ (ppm): 0.91 (d, $\left.J=7.0 \mathrm{~Hz}, 3 \mathrm{H}\right), 1.30(\mathrm{t}, J=$ $7.0 \mathrm{~Hz}, 3 \mathrm{H}), 1.31$ (t, $J=7.1 \mathrm{~Hz}, 3 \mathrm{H}), 1.80-1.95(\mathrm{~m}, 1 \mathrm{H}), 2.24-2.38$ (m, 1H), 2.40-2.58 (m, 1H), $3.49(\mathrm{~s}, 3 \mathrm{H}), 3.90-4.02(\mathrm{~m}, 1 \mathrm{H}), 4.03-$ 4.27 (m, 4H), 7.20-7.62 (m, 10H). ${ }^{13} \mathrm{C}$ NMR (60 MHz): $\delta(\mathrm{ppm})$ : 16.61, $\left(\mathrm{OCH}_{2} \mathrm{CH}_{3}\right), 16.72\left(\mathrm{OCH}_{2} \mathrm{CH}_{3}\right), 18.92\left(\mathrm{CHCH}_{3}\right), 27.97$ $\left(\mathrm{C}\left(\mathrm{CH}_{3}\right)_{3}\right), 35.16\left(\mathrm{~d}, J_{\mathrm{PC}}=4.9 \mathrm{~Hz}, \mathrm{CH}_{2}\right), 37.74\left(\mathrm{~d}, J_{\mathrm{PC}}=14.4 \mathrm{~Hz}\right.$, $\left.\mathrm{CHCH}_{3}\right), 59.52\left(\mathrm{~d}, J_{\mathrm{PC}}=158 \mathrm{~Hz}, \mathrm{CHP}\right), 62.30\left(\mathrm{~d}, J_{\mathrm{PC}}=6.60 \mathrm{~Hz}\right.$,

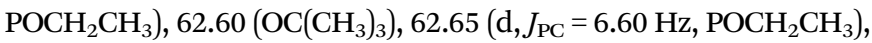
$127.95(\mathrm{Ph}), 128.41(\mathrm{Ph}), 128.45(\mathrm{Ph}), 128.57(\mathrm{Ph}), 128.71(\mathrm{Ph})$, $128.84(\mathrm{Ph}), 128.86(\mathrm{Ph}), 128.93(\mathrm{Ph}), 130.18(\mathrm{Ph}), 130.28(\mathrm{Ph})$, $135.70(\mathrm{Ph}), 135.74(\mathrm{Ph}), 137.53(\mathrm{Ph}), 139.58(\mathrm{Ph}), 169.72(\mathrm{CN})$, 175.44 (CO), ${ }^{31} \mathrm{P}$ NMR (121 MHz): $\delta$ (ppm): 24.0.

[1S-(Benzhydrylidene-amino)-3R-cyano-3-methyl-propyl]phosphonic acid diethyl ester (4g). Colorless oil. $[\alpha]_{\mathrm{D}}^{20}=17.1$ (c $0.8, \mathrm{CHCl}_{3}$ ). HPLC conditions: Chiralpack AD-H (hexaneIPA 95:5, flow rate: $0.8 \mathrm{~mL} \min ^{-1}, 256 \mathrm{~nm}, 5{ }^{\circ} \mathrm{C}$ ) major diastereomer: $t_{\text {major }}=53.4 \mathrm{~min}$ and $t_{\text {minor }}=22.5 \mathrm{~min}$; minor diastereomer: $t_{\text {major }}=27.7 \mathrm{~min}$ and $t_{\text {minor }}=69.2 \mathrm{~min}$. Major diastereomer: ${ }^{1} \mathrm{H}$ NMR (500 MHz): $\delta(\mathrm{ppm}): 1.02(\mathrm{~d}, J=7.0 \mathrm{~Hz}$, $3 \mathrm{H}), 1.24(\mathrm{t}, J=7.0 \mathrm{~Hz}, 3 \mathrm{H}), 1.28(\mathrm{t}, J=7.1 \mathrm{~Hz}, 3 \mathrm{H}), 1.98-2.10$ $(\mathrm{m}, 1 \mathrm{H}), 2.22-2.70(\mathrm{~m}, 2 \mathrm{H}), 3.88-4.00(\mathrm{~m}, 1 \mathrm{H}), 4.00-4.20$ $(\mathrm{m}, 2 \mathrm{H}), 7.19-7.62(\mathrm{~m}, 10 \mathrm{H}) .{ }^{13} \mathrm{C} \mathrm{NMR}(60 \mathrm{MHz}): \delta(\mathrm{ppm})$ : 16.53, $\left(\mathrm{OCH}_{2} \mathrm{CH}_{3}\right)$, 16.60, $\left(\mathrm{OCH}_{2} \mathrm{CH}_{3}\right), 18.63\left(\mathrm{CH}_{3}\right), 23.02$ $\left(\mathrm{d}, J_{\mathrm{PC}}=16.2 \mathrm{~Hz}, \mathrm{CHCH}_{3}\right), 36.34\left(\mathrm{~d}, J_{\mathrm{PC}}=4.3 \mathrm{~Hz}, \mathrm{CH}_{2}\right), 59.14$ $\left(\mathrm{d}, J_{\mathrm{PC}}=157.34 \mathrm{~Hz}, \mathrm{CHP}\right), 62.78\left(\mathrm{~d}, J_{\mathrm{PC}}=7.89 \mathrm{~Hz}, \mathrm{POCH}_{2} \mathrm{CH}_{3}\right)$, $65.40\left(\mathrm{~d}, J_{\mathrm{PC}}=6.54 \mathrm{~Hz}, \mathrm{POCH}_{2} \mathrm{CH}_{3}\right), 122.68(\mathrm{CHCN}), 128.13(\mathrm{Ph})$, $128.32(\mathrm{Ph}), 128.46(\mathrm{Ph}), 128.48(\mathrm{Ph}), 128.48(\mathrm{Ph}), 128.56(\mathrm{Ph})$, $128.68(\mathrm{Ph}), 128.90(\mathrm{Ph}), 128.91(\mathrm{Ph}), 129.0(\mathrm{Ph}), 129.08(\mathrm{Ph})$, $130.1(\mathrm{Ph}), 130.65(\mathrm{Ph}), 132.46(\mathrm{Ph}), 135.06(\mathrm{Ph}), 135.32(\mathrm{Ph})$, $139.12(\mathrm{Ph}), 139.25(\mathrm{Ph}), 171.90(\mathrm{CN}) .{ }^{31} \mathrm{P}$ NMR (121 MHz): $\delta$ (ppm): 22.8. Minor diastereomer: ${ }^{1} \mathrm{H}$ NMR (500 $\left.\mathrm{MHz}\right)$ : $\delta$ (ppm): 1.18 (d, $J=7.1 \mathrm{~Hz}, 3 \mathrm{H}), 1.23(\mathrm{t}, J=7.1 \mathrm{~Hz}, 3 \mathrm{H}), 1.29$ $(\mathrm{t}, J=7.1 \mathrm{~Hz}, 3 \mathrm{H}), 1.98-2.10(\mathrm{~m}, 1 \mathrm{H}), 2.22-2.70(\mathrm{~m}, 2 \mathrm{H}), 3.88-4.0$ $(\mathrm{m}, 1 \mathrm{H}), 4.0-4.2(\mathrm{~m}, 2 \mathrm{H}), 7.19-7.62(\mathrm{~m}, 10 \mathrm{H}) .{ }^{13} \mathrm{C}$ NMR (60 MHz): $\delta$ (ppm): 16.53, $\left(\mathrm{OCH}_{2} \mathrm{CH}_{3}\right), 16.60,\left(\mathrm{OCH}_{2} \mathrm{CH}_{3}\right)$, $17.70\left(\mathrm{CH}_{3}\right), 22.69\left(\mathrm{~d}, J_{\mathrm{PC}}=15.2 \mathrm{~Hz}, \mathrm{CHCH}_{3}\right), 35.94\left(\mathrm{~d}, J_{\mathrm{PC}}=\right.$ $4.8 \mathrm{~Hz}, \mathrm{CH}_{2}$ ), 59.20 (d, $\left.J_{\mathrm{PC}}=159.09 \mathrm{~Hz}, \mathrm{CHP}\right), 62.87\left(\mathrm{~d}, J_{\mathrm{PC}}=4.41\right.$ $\mathrm{Hz}, \mathrm{POCH}_{2} \mathrm{CH}_{3}$ ), $62.97\left(\mathrm{~d}, J_{\mathrm{PC}}=4.0 \mathrm{~Hz}, \mathrm{POCH}_{2} \mathrm{CH}_{3}\right), 122.04$ (CHCN), $128.13(\mathrm{Ph}), 128.32(\mathrm{Ph}), 128.46(\mathrm{Ph}), 128.48(\mathrm{Ph})$, $128.48(\mathrm{Ph}), 128.56(\mathrm{Ph}), 128.68(\mathrm{Ph}), 128.90(\mathrm{Ph}), 128.91(\mathrm{Ph})$, $129.0(\mathrm{Ph}), 129.08(\mathrm{Ph}), 130.1(\mathrm{Ph}), 130.65(\mathrm{Ph}), 132.46(\mathrm{Ph})$, 135.06 (Ph), $135.32(\mathrm{Ph}), 139.12(\mathrm{Ph}), 139.25(\mathrm{Ph}), 172.61(\mathrm{CN})$.
${ }^{31} \mathrm{P}$ NMR (121 MHz): $\delta$ (ppm): 22.8. MS (ESI): $m / z=399.18296$ $[\mathrm{M}+\mathrm{H}]^{+}$. Calcd for $\mathrm{C}_{22} \mathrm{H}_{28} \mathrm{~N}_{2} \mathrm{O}_{3} \mathrm{P}: 399.18321$.

[1-(Benzhydrylidene-amino)-3-cyano-2-phenyl-propyl]-phosphonic acid diethyl ester (4h). Colorless oil. HPLC conditions: Chiralpack AD-H (hexane-IPA 95:5, flow rate: $1 \mathrm{ml} \mathrm{min}^{-1}, 256 \mathrm{~nm}, 5{ }^{\circ} \mathrm{C}$ ) major diastereomer: $t_{\text {major }}=32.7 \mathrm{~min}$ and $t_{\text {minor }}=62.8 \mathrm{~min}$; minor diastereomer: $t_{\text {major }}=27.7 \mathrm{~min}$ and $t_{\text {minor }}=69.2 \mathrm{~min}$. Major diastereomer: ${ }^{1} \mathrm{H}$ NMR (500 MHz): $\delta(\mathrm{ppm}): 1.24(\mathrm{t}, J=$ $7.05 \mathrm{~Hz}, 3 \mathrm{H}), 1.29(\mathrm{t}, J=7.03 \mathrm{~Hz}, 3 \mathrm{H}), 3.30\left(\mathrm{dd}, J_{\mathrm{HaHb}}=17.22 \mathrm{~Hz}\right.$, $\left.J_{\mathrm{HH}}=5.59 \mathrm{~Hz}, 1 \mathrm{H}\right), 3.55\left(\mathrm{dd}, J_{\mathrm{HaHb}}=17.22 \mathrm{~Hz}, J_{\mathrm{HH}}=3.98 \mathrm{~Hz}, 1 \mathrm{H}\right)$, 3.71-3.80 (m, 1H), 3.99-4.16 (m, 5H), 7.04-7.62 (m, 15 $\left.\mathrm{H}_{\mathrm{ar}}\right)$. ${ }^{13} \mathrm{C} \mathrm{NMR}$ (60 MHz): $\delta(\mathrm{ppm}): 16.7,\left(\mathrm{~d}, J_{\mathrm{PC}}=5.71 \mathrm{~Hz}, \mathrm{CH}_{3}\right), 16.7$, $\left(\mathrm{d}, J_{\mathrm{PC}}=5.66 \mathrm{~Hz}, \mathrm{CH}_{3}\right), 18.7\left(\mathrm{~d}, J_{\mathrm{PC}}=4.03 \mathrm{~Hz}, \mathrm{CH}_{2}\right), 44.0\left(\mathrm{~d}, J_{\mathrm{PC}}=\right.$ $3.42 \mathrm{~Hz}, \mathrm{CHPh}), 62.9\left(\mathrm{~d}, J_{\mathrm{PC}}=7.0 \mathrm{~Hz}, \mathrm{OCH}_{2}\right), 63.1\left(\mathrm{~d}, J_{\mathrm{PC}}=\right.$ $\left.7.21 \mathrm{~Hz}, \mathrm{OCH}_{2}\right), 65.4$ (d, $\left.J_{\mathrm{PC}}=155.45 \mathrm{~Hz}, \mathrm{CHP}\right), 119.6\left(\mathrm{CH}_{2} \mathrm{CN}\right)$, $127.8(\mathrm{Ph}), 127.8(\mathrm{Ph}), 127.8(\mathrm{Ph}), 128.2(\mathrm{Ph}), 128.4(\mathrm{Ph}), 128.4$ (Ph), $128.6(\mathrm{Ph}), 128.9(\mathrm{Ph}), 129.0(\mathrm{Ph}), 129.5(\mathrm{Ph}), 131.0(\mathrm{Ph})$, $135.0\left(\mathrm{~d}, J_{\mathrm{PC}}=2.63 \mathrm{~Hz}, \mathrm{C}_{\mathrm{Arq}}\right), 139.1\left(\mathrm{~d}, J_{\mathrm{PC}}=3.73 \mathrm{~Hz}, \mathrm{C}_{\mathrm{Arq}}\right), 139.3$ $\left(\mathrm{d}, J_{\mathrm{PC}}=13.97 \mathrm{~Hz}, \mathrm{C}_{\mathrm{Arq}} \mathrm{CH}\right), 172.9\left(\mathrm{~d}, J_{\mathrm{PC}}=15,59 \mathrm{~Hz}, \mathrm{Ph}_{2} \mathrm{CN}\right) .{ }^{31} \mathrm{P}$ NMR (121 MHz): $\delta$ (ppm): 21.80. Minor diastereomer: ${ }^{1} \mathrm{H}$ NMR (500 MHz): $\delta(\mathrm{ppm}): 1.10(\mathrm{t}, J=7.03 \mathrm{~Hz}, 3 \mathrm{H}), 1.14(\mathrm{t}, J=7.0 \mathrm{~Hz}$, $3 \mathrm{H}), 2.85\left(\mathrm{dd}, J_{\mathrm{HaHb}}=16.52 \mathrm{~Hz}, J_{\mathrm{HH}}=9.80 \mathrm{~Hz}, 1 \mathrm{H}\right), 3.10(\mathrm{dd}$, $\left.J_{\mathrm{HaHb}}=16.52 \mathrm{~Hz}, J_{\mathrm{HH}}=4.0 \mathrm{~Hz}, 1 \mathrm{H}\right), 3.51-3.58\left(\mathrm{dd}, J_{\mathrm{HaHb}}=\right.$ $\left.13.25 \mathrm{~Hz}, J_{\mathrm{HH}}=3.98 \mathrm{~Hz}, 1 \mathrm{H}\right), 3.71-3.8(\mathrm{~m}, 1 \mathrm{H}), 3.99-4.16(\mathrm{~m}, 5 \mathrm{H})$, 7.04-7.62 (m, 15H $\mathrm{Har}) \cdot{ }^{13} \mathrm{C} \mathrm{NMR}(60 \mathrm{MHz}): \delta(\mathrm{ppm}): 16.4,\left(\mathrm{~d}, J_{\mathrm{PC}}=\right.$ $6.11 \mathrm{~Hz}, \mathrm{CH}_{3}$ ), 16.5, (d, $\left.J_{\mathrm{PC}}=6.12 \mathrm{~Hz}, \mathrm{CH}_{3}\right), 18.7$ (d, $J_{\mathrm{PC}}=4.03 \mathrm{~Hz}$, $\mathrm{CH}_{2}$ ), $50.1\left(\mathrm{~d}, J_{\mathrm{PC}}=16.17 \mathrm{~Hz}, \mathrm{CHPh}\right), 62.9\left(\mathrm{~d}, J_{\mathrm{PC}}=7 \mathrm{~Hz}, \mathrm{OCH}_{2}\right)$, $63.1\left(\mathrm{~d}, J_{\mathrm{PC}}=7.21 \mathrm{~Hz}, \mathrm{OCH}_{2}\right), 59.8\left(\mathrm{~d}, J_{\mathrm{PC}}=168.87 \mathrm{~Hz}, \mathrm{CHP}, 127.8\right.$ (Ph), 127.8 (Ph), 127.8 (Ph), $128.2(\mathrm{Ph}), 128.4(\mathrm{Ph}), 128.4(\mathrm{Ph})$, 128.6 (Ph), 128.9 (Ph), $129.0(\mathrm{Ph}), 129.0(\mathrm{Ph}), 131.0(\mathrm{Ph}), \mathrm{CH}_{2} \mathrm{CN}$, $\mathrm{C}_{\text {Arq }}$ and $\mathrm{Ph}_{2} \mathrm{CN}$ ) can't be assigned. ${ }^{31} \mathrm{P}$ NMR (121 MHz): $\delta(\mathrm{ppm})$ : 21.8. MS (ESI): major diastereomer: $m / z=461.1985[\mathrm{M}+\mathrm{H}]^{+}$, minor diastereomer: $m / z=461.2001[\mathrm{M}+\mathrm{H}]^{+}$. Calcd for $\mathrm{C}_{27} \mathrm{H}_{30} \mathrm{~N}_{2} \mathrm{O}_{3} \mathrm{P}$ : 461.1994.

[1-(Benzhydrylene-amino)-3-nitro-2-phenyl-1-propyl]-phosphonic acid diethyl ester (4i). Pale yellow oil. HPLC conditions: Chiralpack AD-H (hexane-IPA 95:5, flow rate: $0.5 \mathrm{ml} \mathrm{min}^{-1}$, $222 \mathrm{~nm}$ ) major diastereomer: $t_{\text {major }}=32.7 \mathrm{~min}$ and $t_{\text {minor }}=$ $62.8 \mathrm{~min}$; minor diastereomer: $t_{\text {major }}=27.7 \mathrm{~min}$ and $t_{\text {minor }}=$ $69.2 \mathrm{~min}$. Major diastereomer: ${ }^{1} \mathrm{H}$ NMR: (500 MHz), $\delta(\mathrm{ppm})$ : $1.20\left(\mathrm{t}, J_{\mathrm{HH}}=7.06 \mathrm{~Hz}, 3 \mathrm{H}\right), 1.26\left(\mathrm{t}, J_{\mathrm{HH}}=7.06 \mathrm{~Hz}, 3 \mathrm{H}\right), 3.78-3.97$ $(\mathrm{m}, 1 \mathrm{H}), 3.97-4.11(\mathrm{~m}, 4 \mathrm{H}), 4.15-4.25(\mathrm{~m}, 1 \mathrm{H}), 5.20\left(\mathrm{dd}, J_{\mathrm{HAHM}}=\right.$ $\left.11.4 \mathrm{~Hz}, J_{\mathrm{HAHB}}=14.0 \mathrm{~Hz}, 1 \mathrm{H}\right), 5.55\left(\mathrm{dd}, J_{\mathrm{HBHM}}=4.15 \mathrm{~Hz}, J_{\mathrm{HAHB}}=\right.$ $14.0 \mathrm{~Hz}, 1 \mathrm{H}), 6.9-7.4\left(\mathrm{~m}, 15 \mathrm{H}_{\mathrm{ar}}\right) .{ }^{13} \mathrm{C} \mathrm{NMR}(60 \mathrm{MHz}): \delta(\mathrm{ppm})$ : $16.4,\left(\mathrm{~d}, J_{\mathrm{PC}}=6.11 \mathrm{~Hz}, \mathrm{CH}_{3}\right), 16.5,\left(\mathrm{~d}, J_{\mathrm{PC}}=6.12 \mathrm{~Hz}, \mathrm{CH}_{3}\right), 42.65$ $\left(\mathrm{d}, J_{\mathrm{PC}}=16.40 \mathrm{~Hz}, \mathrm{CHPh}\right), 58.5\left(\mathrm{~d}, J_{\mathrm{PC}}=153.87 \mathrm{~Hz}, \mathrm{CHP}\right), 62.9$ $\left(\mathrm{d}, J_{\mathrm{PC}}=7 \mathrm{~Hz}, \mathrm{OCH}_{2}\right), 63.3\left(\mathrm{~d}, J_{\mathrm{PC}}=7.2 \mathrm{~Hz}, \mathrm{OCH}_{2}\right), 77.4\left(\mathrm{~d}, J_{\mathrm{PC}}=\right.$ $\left.4.03 \mathrm{~Hz}, \mathrm{CH}_{2} \mathrm{NO}_{2}\right), 126.2(\mathrm{Ph}), 126.8(\mathrm{Ph}), 127.2(\mathrm{Ph}), 127.8(\mathrm{Ph})$, $128.2(\mathrm{Ph}), 128.4(\mathrm{Ph}), 128.5(\mathrm{Ph}), 128.6(\mathrm{Ph}), 128.9(\mathrm{Ph}), 129.0$ $(\mathrm{Ph}), 131.2(\mathrm{Ph}), 137.5\left(\mathrm{Ph}_{\mathrm{q}}\right) 148.9\left(\mathrm{Ph}_{\mathrm{q}}\right), 162.7\left(\mathrm{Ph}_{2} \mathrm{CN}\right)$. ${ }^{31} \mathrm{P}$ NMR (121 MHz): $\delta$ 21.8. ${ }^{31} \mathrm{P}$ NMR (121 MHz): $\delta$ (ppm): 21.6. Minor diastereomer: ${ }^{1} \mathrm{H}$ NMR: (500 MHz), $\delta$ (ppm): 1.10 $\left(\mathrm{t}, J_{\mathrm{HH}}=7.14 \mathrm{~Hz}, 6 \mathrm{H}\right), 3.78-3.97(\mathrm{~m}, 1 \mathrm{H}), 3.97-4.11(\mathrm{~m}, 4 \mathrm{H})$, 4.15-4.25 (m, 1H), $4.75\left(\mathrm{dd}, J_{\mathrm{HAHB}}=13.4 \mathrm{~Hz}, J_{\mathrm{HAHM}}=10.8 \mathrm{~Hz}\right.$, $1 \mathrm{H}), 5.11\left(\mathrm{dd}, J_{\mathrm{HAHB}}=13.4 \mathrm{~Hz}, J_{\mathrm{HAHM}}=4.6 \mathrm{~Hz}, 1 \mathrm{H}\right), 5.90$ $\left(\mathrm{d}, J_{\mathrm{HBHM}}=4.15 \mathrm{~Hz}, J_{\mathrm{HAHB}}=14.0 \mathrm{~Hz}, 1 \mathrm{H}\right), 6.9-7.4\left(\mathrm{~m}, 15 \mathrm{H}_{\mathrm{ar}}\right)$. 
${ }^{13} \mathrm{C}$ NMR (60 MHz): $\delta$ (ppm): 16.6, (d, $\left.J_{\mathrm{PC}}=6.10 \mathrm{~Hz}, \mathrm{CH}_{3}\right), 16.6$, $\left(\mathrm{d}, J_{\mathrm{PC}}=6.11 \mathrm{~Hz}, \mathrm{CH}_{3}\right), 42.12\left(\mathrm{~d}, J_{\mathrm{PC}}=15.02 \mathrm{~Hz}, \mathrm{CHPh}\right), 59.8$ $\left(\mathrm{d}, J_{\mathrm{PC}}=151.54 \mathrm{~Hz}, \mathrm{CHP}\right), 62.9\left(\mathrm{~d}, J_{\mathrm{PC}}=7.12 \mathrm{~Hz}, \mathrm{OCH}_{2}\right), 63.4$ $\left(\mathrm{d}, J_{\mathrm{PC}}=7.18 \mathrm{~Hz}, \mathrm{OCH}_{2}\right), 77.8\left(\mathrm{~d}, J_{\mathrm{PC}}=4.03 \mathrm{~Hz}, \mathrm{CH}_{2} \mathrm{NO}_{2}\right), 126.2$ (Ph), 126.8 (Ph), $127.2(\mathrm{Ph}), 127.8(\mathrm{Ph}), 128.2(\mathrm{Ph}), 128.4(\mathrm{Ph})$, 128.5 (Ph), 128.6 (Ph), $128.9(\mathrm{Ph}), 129.0(\mathrm{Ph}), 131.2(\mathrm{Ph}), 137.5$ $\left(\mathrm{Ph}_{\mathrm{q}}\right)$ 148.9 $\left(\mathrm{Ph}_{\mathrm{q}}\right), 162.7\left(\mathrm{Ph}_{2} \mathrm{CN}\right) .{ }^{31} \mathrm{P}$ NMR (121 MHz): $\delta$ (ppm): 23.5.

\section{Conflicts of interest}

There are no conflicts to declare.

\section{Acknowledgements}

Financial support by the Hungarian Scientific Research Found (OTKA No. PD 112166) and from the National Research, Development and Innovation Office (NKFI Grant No. K116034) are gratefully acknowledged. A. S. acknowledges fruitful interactions with Á. Madarász. We thank Professor M. Nógrádi for helpful discussions.

\section{References}

1 (a) J. Oleksyszyn, in Aminophosphonic and Aminophosphinic Acids, ed. V. P. Kukhar and H. R. Hudson, John Wiley and Sons, Chichester, 2000, ch. 15, pp. 537-558; (b) P. Kafarski and B. Lejczak, Phosphorus, Sulfur Silicon Relat. Elem., 1991, 63, 193-215; (c) P. Kafarski and B. Lejczak, Curr. Med. Chem., 2001, 1, 301-312; (d) Z. H. Kudzin, M. H. Kudzin, J. Drabowicz and C. V. Stevens, Curr. Org. Chem., 2011, 15, 2015-2071; (e) G. Wulff and J. Liu, Acc. Chem. Res., 2012, 45, 239-247; $(f)$ G. M. Blackburn, M. W. Bowler, Y. Jin and J. P. Waltho, Biochemistry, 2012, 77, 1083-1096; (g) A. K. Bhattacharya, D. S. Raut, K. C. Rana, I. K. Polanki, M. S. Khan and S. Iram, Eur. J. Med. Chem., 2013, 66, 146-152.

2 (a) J. G. Allen, F. R. Atherton, M. J. Hall, C. H. Hassal, S. W. Holmes, R. W. Lambert, L. J. Nisbet and P. S. Ringrose, Nature, 1978, 272, 56-58; (b) R. Rozenfeld, X. Iturrioz, M. Okada, B. Maigret and C. Llorens-Cortes, Biochemistry, 2003, 42, 14785-14793; (c) F. Orsini, G. Sello and M. Sisti, Curr. Med. Chem., 2010, 17, 264-289; (d) A. Mucha, P. Kafarski and Ł. Berlicki, J. Med. Chem., 2011, 54, 5955-5980; (e) A. K. Bhattacharya, D. S. Raut, K. C. Rana, I. K. Polanki, M. S. Khan and S. Iram, Eur. J. Med. Chem., 2013, 66, 146-152; $(f)$ H. R. Hudson, in Aminophosphonic and Aminophosphinic Acids, ed. V. P. Kukhar and H. R. Hudson, John Wiley and Sons, Chichester, 2000, ch. 13, pp. 443-482.

3 P. Dinér and M. Amedjkouh, Org. Biomol. Chem., 2006, 4, 2091-2096.

4 (a) T. Kiss and I. Lázár in Aminophosphonic and Aminophosphinic Acids, ed. V. P. Kukhar and H. R. Hudson, John Wiley and Sons, Chichester, 2000, ch. 9, pp. 285-325; (b) N. Caccamo, S. Meraviglia, G. Ciceri, G. Gulotta, F. Moschella,
A. Cordova, E. Gulotta, A. Salerno and F. Dieli, Curr. Med. Chem., 2008, 15, 1147-1153; (c) C. Queffélec, M. Petit, P. Janvier, D. A. Knight and B. Bujoli, Chem. Rev., 2012, 112, 3777-3807; (d) Lj. Tusek-Bozic, Curr. Med. Chem., 2013, 20, 2096-2117.

5 For recent reviews see: (a) J.-A. Ma, Chem. Soc. Rev., 2006, 35, 630-636; (b) M. Ordonez, H. Rojas-Cabrera and C. Cativiela, Tetrahedron, 2009, 65, 17-49; (c) Ł. Albrecht, A. Albrecht, H. Krawczyk and K. A. Jorgensen, Chem. - Eur. J., 2010, 16, 28-48; (d) M. Ordonez, J. Viveros-Ceballas and C. Cativiela, Curr. Org. Synth., 2012, 9, 310-341; (e) I. O. Kolodiazhnyi, V. P. Kukhar and A. O. Kolodiazhna, Tetrahedron: Asymmetry, 2014, 25, 865-922; $(f)$ M. Ordonez, J. L. Viveros-Ceballos, C. Cativiela and F. J. Sayago, Tetrahedron, 2015, 71, 1745-1784.

6 For P-C bond formation see: (a) A. B. Smith III, K. M. Yager and C. M. Taylor, J. Am. Chem. Soc., 1995, 117, 10879-10888; (b) M. Mikolajczyk, P. Lyzwa and J. Drabowicz, Tetrahedron: Asymmetry, 1997, 8, 3991-3994; (c) I. M. Lefebvre and S. A. Evans Jr., J. Org. Chem., 1997, 62, 7532-7533For C-C bond formation see: (d) U. Schöllkopf and R. Schütze, Liebigs Ann. Chem., 1987, 45-49; (e) U. Groth, L. Richter and U. Schöllkopf, Liebigs Ann. Chem., 1992, 903-909; $(f)$ S. Hanessian and Y. L. Bennani, Tetrahedron Lett., 1990, 31, 6465-6468; (g) F. Ouazzani, M. L. Roumestant and P. Viallefont, Tetrahedron: Asymmetry, 1991, 2, 913-917For C-N bond formation see: (h) S. E. Denmark, N. Chatani and S. Pansare, Tetrahedron, 1992, 48, 2191-2208; (i) S. Hanessian and Y. L. Bennani, Synthesis, 1994, 1272-1274.

7 For P-C bond formation see: (a) H. Sasai, S. Arai, Y. Tahara and M. Shibasaki, J. Org. Chem., 1995, 60, 6656-6657; (b) T. Akiyama, H. Morita, J. Itoh and K. Fuchibe, Org. Lett., 2005, 7, 2583-2585; (c) G. D. Joly and E. N. Jacobsen, J. Am. Chem. Soc., 2004, 126, 4102-4103; (d) D. Pettersen, M. Marcolini, L. Bernardi, F. Fini, R. P. Herrera, V. Sgarzani and A. Ricci, J. Org. Chem., 2006, 71, 6269-6272; (e) B. Saito, H. Egami and T. Katsuki, J. Am. Chem. Soc., 2007, 129, 1978-1986; $(f)$ G. Zhang, G. Hao, J. Pan, J. Zhang, D. Hu and B. Song, J. Agric. Food Chem., 2016, 64, 4207-4213.

8 For C-C bond formation see: (a) S. Kobayashi, H. Kiyohara, Y. Nakamura and R. Matsubara, J. Am. Chem. Soc., 2004, 126, 6558-6559; (b) Zs. Jászay, G. Németh, T. S. Pham, I. Petneházy, A. Grün and L. Tőke, Tetrahedron: Asymmetry, 2005, 16, 3837-3840; (c) H. Kiyohara, R. Matsubara and S. Kobayashi, Org. Lett., 2006, 8, 5333-5335; (d) Zs. Jászay, T. S. Pham, G. Németh, P. Bakó, I. Petneházy and L. Tőke, Synlett, 2009, 1429-1432; (e) T. S. Pham, J. B. Czirok, L. Balázs, K. Pál, M. Kubinyi, I. Bitter and Zs. Jászay, Tetrahedron: Asymmetry, 2011, 22, 480-486; $(f)$ K. Bera and I. N. N. Namboothiri, J. Org. Chem., 2015, 80, 1402-1413.

9 (a) M. Alonso-Lopez, J. Jimenez-Barbero, M. Martin-Lomas and S. Penades, Tetrahedron, 1988, 44, 1535-1543; (b) M. Alonso-Lopez, M. Martin-Lomas, S. Penades, C. Bosso and J. Ulrich, J. Carbohydr. Chem., 1986, 5, 705; (c) D. A. H. Van Maarschalkerwaart, N. P. Willard and U. K. Pandit, Tetrahedron, 1992, 48, 8825; (d) C. Vicent, C. M. Martin-Lomas and S. Penades, Tetrahedron, 1989, 45, 3605. 
10 (a) S. Jarosz and A. Listkowski, Curr. Org. Chem., 2006, 10, 643-662; (b) S. Woodward, M. Diéguez and O. Pamies, Coord. Chem. Rev., 2010, 254, 2007-2030.

11 (a) P. Bakó, T. Kiss and L. Töke, Tetrahedron Lett., 1997, 38, 7259; (b) P. Bakó, Á. Szöllősy, P. Bombicz and L. Töke, Synlett, 1997, 291; (c) P. Bakó, K. Vizvardi, Z. Bajor and L. Tőke, Chem. Commun., 1998, 1193; (d) P. Bakó, K. Vízvárdi, S. Toppet, E. Van der Eycken, G. J. Hoornaert and L. Tőke, Tetrahedron, 1998, 54, 14975-14988.

12 (a) A. Makó, Z. Rapi, L. Drahos, Á. Szöllősy, G. Keglevich and P. Bakó, Tetrahedron: Asymmetry, 2010, 7, 424-431; (b) P. Bakó, T. Bakó, A. Mészáros, G. Keglevich, Á. Szöllősy, S. Bodor, A. Makó and L. Tőke, Synlett, 2004, 643-646; (c) Z. Rapi,
P. Bakó, G. Keglevich, Á. Szöllősy, L. Drahos and A. Botyánszki, Tetrahedron: Asymmetry, 2012, 23, 489-496; (d) P. Bakó, G. Keglevich and Z. Rapi, Lett. Org. Chem., 2010, 7, 645-656.

13 T. Itoh and S. Shirakami, Heterocycles, 2001, 55, 37-43.

14 (a) A. Makó, K. D. Menyhárd, P. Bakó, G. Keglevich and L. Töke, J. Mol. Struct., 2008, 892, 336-342; (b) Z. Rapi, A. Grün, G. Keglevich, A. Stirling and P. Bakó, New J. Chem., 2016, 40, 7856-7865.

15 J. D. Chai and M. Head-Gordon, Phys. Chem. Chem. Phys., 2008, 10, 6615-6620.

16 A. V. Marenich, C. J. Cramer and D. G. Truhlar, J. Phys. Chem. B, 2009, 113, 6378-6396. 